\title{
The Efficacy of Polyacrylamide and Related Compounds to Remove Microorganisms and Nutrients from Animal Wastewater
}

\author{
James A. Entry* and R. E. Sojka
}

\begin{abstract}
Polyacrylamide (PAM) is an effective flocculent and we hypothesized that it would reduce transport of microorganisms and nutrients in water flowing over and through soil. We measured nutrients, total coliform bacteria, fecal coliform bacteria, fecal streptococci, active and total fungi, and active and total bacteria in water leached through cattle, fish, and swine manure, PAM, PAM + Al(SO $)_{3}$, or PAM + $\mathrm{CaO}$ mixtures, and $25-\mathrm{cm}$ sand columns. In the laboratory study, PAM, PAM + Al( $\left(\mathrm{SO}_{4}\right)_{3}$, and PAM + CaO treatments reduced total coliform bacteria, fecal coliform bacteria, and fecal streptococci by 10 to 1000-fold in water leached through sand columns. Polyacrylamide + $\mathrm{Al}\left(\mathrm{SO}_{4}\right)_{3}$ and $\mathrm{PAM}+\mathrm{GaO}_{\mathrm{aO}}$ treatments reduced the concentration of $\mathrm{NH}_{6}$ total $\mathrm{P}$, and $\mathrm{PO}_{4}$ by 20 to $60 \%$ in leachate when cattle and swine manure were applied. In a field study, after water flowed over all three manure sources and then PAM, PAM + Al(SO, $)_{3}$, or PAM + $\mathrm{CaO}$ in furrows, total coliform bacteria, fecal coliform bacteria, and fecal streptococci were reduced by 10 - to 1000 -fold in water fowing 1 and $27 \mathrm{~m}$ downstream of the treatments compared with the control treatment. When water flowed over cattle manure and then PAM + $\mathrm{Al}\left(\mathrm{SO}_{4}\right)_{3}$ or PAM $+\mathrm{CaO}_{1} \mathrm{PO}_{4}$ concentration was reduced by 50 to $70 \%$ and total $P$ concentration was reduced by 0 to $75 \%$ in water 27 m downstream of the treatments compared with the PAM alone treatment. Polyacrylamide $+\mathrm{Al}\left(\mathrm{SO}_{4}\right)_{3}$ and PAM $+\mathrm{CaO}$ should be able to reduce the numbers of enteric microorganisms and nutrient concentration in animal wastewater running off animal confinement areas, reducing the amount of these pollutants entering surface and ground waters.
\end{abstract}

$\mathrm{T}$ HE number and size of animal production operations in the USA has steadily increased for several decades (USEPA, 1998). Large volumes of animal waste are generated as wastewater from urine and animal washing and as semisolid or solid manure. Pollution of surface flow and ground water from the application of animal waste has been well documented (Mallin et al., 1997; Mawdsley et al., 1995; Khaeel et al., 1980). Liquidwaste discharge onto soil initiates solute and microbe movement into the soil that follows natural ground water drainage patterns and may contaminate adjoining surface water. These same bodies of water are often used for sources of drinking water and/or for recreational activities. Human contact with recreational waters containing intestinal pathogens is an effective method to spread disease. Therefore, it is critical to maintain the quality of our lakes and streams by keeping them free of intestinal pathogens and excess nutrients.

Management practices that are currently used to mitigate the input of pollutants from animal waste to surface and ground water include control of animal numbers (Gary et al., 1985; Jawson et al., 1982), control of animal

USDA-ARS, Northwest Irrigation and Soils Research Lab., 3793 North 3600 East, Kimberly, ID 83341. Received 16 Dec. 1999. *Corresponding author (jentry@kimberly.ars.pn.usbr.gov).

Published in J. Environ. Qual. 29:1905-1914 (2000). diet (Diez-Gonzalez et al., 1998), constructed wetlands, and riparian filterstrips (Coyne et al., 1998, 1995; Walker et al., 1990; Young et al., 1980). However, there are several problems with vegetative systems: (i) the establishment of vegetation in wetlands or riparian areas can take from months to years to establish, (ii) vegetative systems are not effective when vegetation is not growing (winter months) and can become nutrient sources rather than nutrient sinks, (iii) riparian filterstrips or constructed wetlands are effective for only small quantities of runoff (relatively infrequent or low-intensity runoff events) since continuous application can quickly overload the system and nullify the ability of the vegetation to take up nutrients, and (iv) vegetative systems cannot be transported to the site of a waste spill or runoff area. Therefore, even when best management practices are used, animal production operations can sometimes contribute large amounts of nutrients and enteric microorganisms to watercourses.

Polyacrylamide has been used in furrow-irrigated agriculture for erosion control and increased infiltration (Lentz et al., 1992; Lentz and Sojka, 1994; Sojka et al., 1998a,b). Lentz et al. (1998) and Lentz and Sojka (1994) reported that PAM treatment reduced sediment loss rate over time with improvement of the runoff water quality parameters ortho-P, total $P$, nitrate, and biological oxygen demand. Runoff sediment reduction averaged $94 \%$ and infiltration increased $15 \%$ in a series of studies conducted over 3 yr. Subsequent studies have further documented the capacity of PAM treatment of furrow irrigation water to reduce sediments, nutrients, and pesticides in irrigation water (Agassi et al., 1995; Bahr and Stieber, 1996; Singh et al., 1996; Sojka et al., 1998a,b).

Recently, Sojka and Entry (2000) also documented large reductions in microorganisms in water flowing in 1- to $30-\mathrm{m}$ furrows in irrigated crop land after applying 15 to $30 \mathrm{~g}$ of PAM directly to the soil in the first $1.0 \mathrm{~m}$ of the furrow. Efficacious treatment for sediment reduction has been possible in most instances with net PAM application rates of only about $1 \mathrm{~kg} \mathrm{ha}^{-1}\left(1 \mathrm{lb}^{-1} \mathrm{acre}^{-1}\right)$ applied at a concentration of $10 \mu \mathrm{g} \mathrm{PAM} \mathrm{mL}^{-1}$ in the first $1.0 \mathrm{~m}$ of the furrow. The objective of this study was to: (i) determine the efficacy of PAM, PAM $+\mathrm{Al}\left(\mathrm{SO}_{4}\right)_{3}$, and PAM $+\mathrm{CaO}$ to remove coliform bacteria, active bacteria and fungi, and nutrients from three types of animal wastewater by sampling leachate draining from sand columns and (ii) determine the efficacy of PAM, $\mathrm{PAM}+\mathrm{Al}\left(\mathrm{SO}_{4}\right)_{3}$, and $\mathrm{PAM}+\mathrm{CaO}$ to remove coliform bacteria, active bacteria and fungi, and nutrients from three types of animal wastewater in surface runoff in silt loam textured soils.

Abbreviations: AMD, acryamide monomer; PAM, polyacrylamide. 
Table 1. Efficacy of polyacrylamide (PAM), PAM + Al $\left(\text { SO }_{4}\right)_{3}$, and PAM + CaO to remove total and fecal coliform bacteria, fecal streptococci, active and total bacteria, and active and total fungi through columns filled with clean sand. $\dagger$

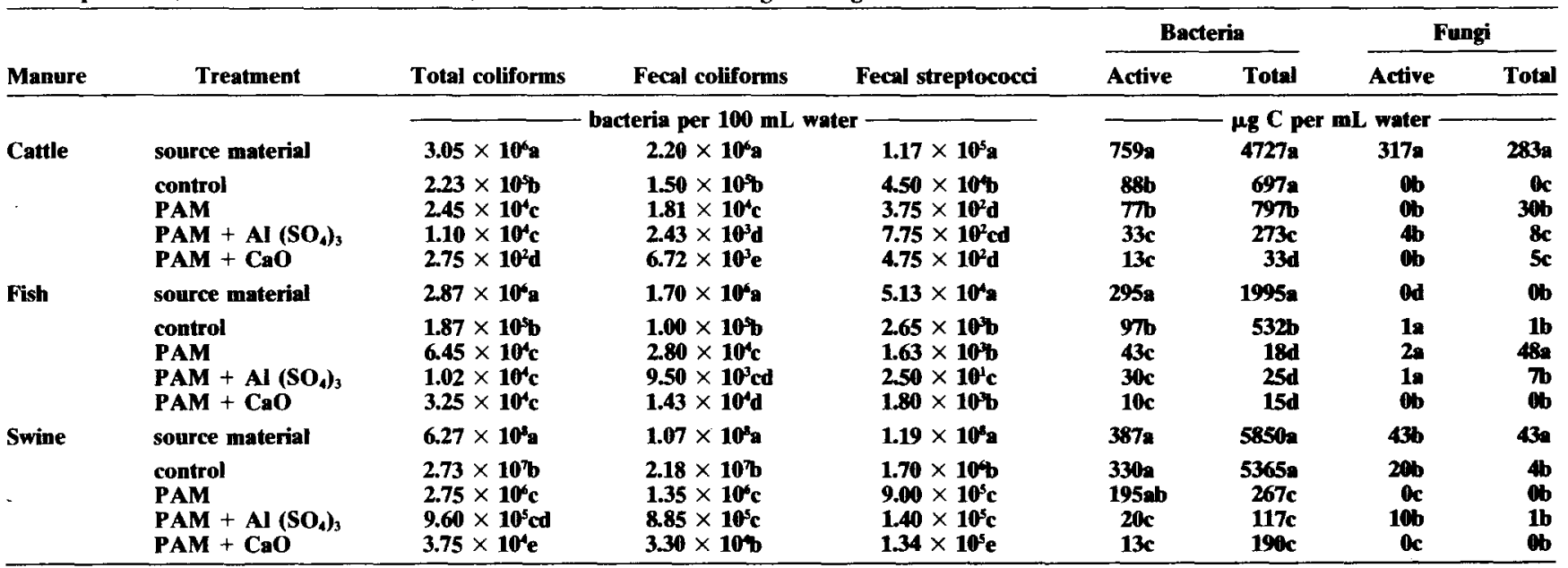

$\dagger$ In each column, values followed by the same letter are not significantly different as determined by the least square means test $(P \leq 0.05), n=16$.

\section{MATERIALS AND METHODS}

\section{Column Study}

\section{Experimental Design}

The column study was arranged in a completely random design (Kirk, 1982) consisting of four treatments: (i) PAM, (ii) $\mathrm{PAM}+\mathrm{Al}\left(\mathrm{SO}_{4}\right)_{3}$, (iii) $\mathrm{PAM}+\mathrm{CaO}$, and (iv) a control having no amendment with three different manure types (cattle, fish, and swine). Forty-eight columns were prepared for the study. There were four replications (columns) with four observations (four samples taken from each leachate sample as sampling error) for each treatment $\times$ manure combination (four treatments $x$ three manure types $x$ four replications $x$ four observations per column).

\section{Waste Material}

Cattle (Bos taurus) and swine (Sus scrofa) manure was fine-grained material obtained from animals on local farms given feed rations with dietary supplements. Fish manure was obtained from rainbow trout (Oncorhynchus mykiss) raised at the Clear Springs Hatchery, Haggerman, ID, which were fed a blended diet of $40 \%$ fish meal, $30 \%$ plant proteincarbohydrate, $15 \%$ fish oil, $10 \%$ nonfish protein, and $5 \%$ binders, vitamins and minerals. Concentrations of total coliform bacteria, fecal coliform bacteria, fecal streptococci, active and total fungi, and active and total bacteria for each manure type are listed as source material in Table 1 for the column study and Table 3 for the surface flow study. Nutrient concentrations in each manure type are listed as source material in Table 2 for the column study and Tables 4, 5, and 6 for the surface flow study.

\section{Column Description}

A 2.00 -mm wire screen was cut into squares $(125 \times 125$ $\mathrm{mm}$ ) and secured to the bottom of each 10.0-cm-diameter $X$ 40-cm-long polyvinyl chloride cylinder (Fig. 1). A 12-cm-diameter funnel was placed below each column and the apparatus was secured to a ring stand. Three kilograms of sand was placed in each column (columns were filled to $30 \mathrm{~cm}$ ) leaving a $10-\mathrm{cm}$ space at the top of each column. Sand in columns was a combination of the following size grains by weight: $0.28 \% \geq 3.35 \mathrm{~mm}, 4.86 \% \geq 2.362 \mathrm{~mm}, 21.64 \% \geq 1.379 \mathrm{~mm}$, $11.05 \% \geq 1.000 \mathrm{~mm}, 28.9 \% \geq 0.600 \mathrm{~mm}, 24.26 \% \geq 0.246$ $\mathrm{mm}, 6.60 \% \geq 0.149 \mathrm{~mm}, 1.00 \% \geq 0.125 \mathrm{~mm}$, and $1.40 \%>$ $0.125 \mathrm{~mm}$. Sand in columns was loosely packed and then repeatedly washed with distilled water to flush microorganisms

Table 2. Efficacy of polyacrylamide (PAM), PAM + Al (SO $)_{3}$, and PAM + CaO to filter nutrients through columns filled with clean sand. $\dagger$

\begin{tabular}{|c|c|c|c|c|c|c|c|c|}
\hline Manure & Treatment & $\mathbf{N O}_{3}$ & $\mathbf{N H}_{4}$ & Total P & $\mathbf{P O}_{4}$ & $\mathbf{K}$ & $\mathrm{Ca}$ & Mg \\
\hline \multirow[t]{2}{*}{ Cattle } & source material & $104.83 \mathrm{a}$ & $490.07 \mathrm{a}$ & $2630.00 \mathrm{a}$ & $1596.00 \mathrm{a}$ & $1630.00 \mathrm{a}$ & $711.70 a$ & 1981.01: \\
\hline & $\begin{array}{l}\text { control } \\
\text { PAM } \\
\text { PAM }+\mathbf{A l}\left(\mathrm{SO}_{4}\right)_{3} \\
\mathbf{P A M}+\mathrm{CaO}\end{array}$ & $\begin{array}{l}0.07 e \\
0.12 e \\
0.02 e \\
0.15 e\end{array}$ & $\begin{array}{l}1.94 c \\
0.33 d \\
0.61 d \\
0.44 d\end{array}$ & $\begin{array}{r}112.16 b \\
66.86 b \\
42.47 \mathrm{c} \\
8.97 d\end{array}$ & $\begin{array}{l}3.52 \mathrm{c} \\
1.85 \mathrm{~d} \\
1.56 \mathrm{~d} \\
0.18 \mathrm{e}\end{array}$ & $\begin{array}{r}22.51 c \\
9.28 d \\
1.66 \mathrm{e} \\
2.73 \mathrm{e}\end{array}$ & $\begin{array}{l}47.12 \mathrm{~d} \\
87.89 \mathrm{c} \\
3.66 \mathrm{f} \\
2.86 \mathrm{f}\end{array}$ & $\begin{array}{l}12.00 \mathrm{c} \\
2.84 \mathrm{~d} \\
3.22 \mathrm{~d} \\
1.68 d\end{array}$ \\
\hline \multirow[t]{2}{*}{ Fish } & source material & $5.97 \mathrm{c}$ & 271.506 & $1309.60 \mathrm{a}$ & $1465.30 \mathrm{~m}$ & $86.65 b$ & $1428.37 b$ & 5468tb \\
\hline & $\begin{array}{l}\text { control } \\
\text { PAM } \\
\text { PAM }+\mathbf{A l}\left(\mathbf{S O}_{4}\right)_{3} \\
\mathbf{P A M}+\mathbf{C a O}\end{array}$ & $\begin{array}{l}0.04 \mathrm{e} \\
0.04 \mathrm{e} \\
0.03 \mathrm{e} \\
0.01 \mathrm{e}\end{array}$ & $\begin{array}{l}\text { 0.00e } \\
0.00 \text { e } \\
0.04 \text { e } \\
0.00 \text { e }\end{array}$ & $\begin{array}{l}35.74 c \\
39.68 c \\
37.23 c \\
35.38 c\end{array}$ & $\begin{array}{l}1.29 d \\
1.00 d \\
1.70 d \\
1.48 d\end{array}$ & $\begin{array}{l}1.82 \mathrm{e} \\
2.57 \mathrm{e} \\
3.70 \mathrm{e} \\
2.62 \mathrm{e}\end{array}$ & $\begin{array}{l}5.48 f \\
10.49 \mathrm{ef} \\
14.00 \mathrm{e} \\
6.70 \mathrm{f}\end{array}$ & $\begin{array}{l}6.8 \% \mathrm{~cd} \\
5.54 \mathrm{~d} \\
10.37 \mathrm{c} \\
4.00 \mathrm{~d}\end{array}$ \\
\hline \multirow[t]{2}{*}{ Swine } & source material & $10.17 b$ & $946.09 \mathrm{a}$ & $3359.33 n$ & $2940.53 a$ & $875.06 \mathrm{n}$ & $69.02 c$ & $37.65 \mathrm{~b}$ \\
\hline & $\begin{array}{l}\text { control } \\
\text { PAM } \\
\text { PAM }+\mathbf{A l}\left(\mathrm{SO}_{4}\right)_{3} \\
\text { PAM }+\mathbf{C a O}\end{array}$ & $\begin{array}{r}17.94 b \\
5.26 c \\
6.42 c \\
2.81 d\end{array}$ & $\begin{array}{l}0.61 d \\
0.41 d \\
0.20 d \\
0.08 \mathrm{~d}\end{array}$ & $\begin{array}{l}70.91 \mathrm{bc} \\
66.53 \mathrm{bc} \\
44.15 \mathrm{c} \\
48.82 \mathrm{c}\end{array}$ & $\begin{array}{l}5.60 b \\
2.04 c \\
3.35 c \\
4.03 c\end{array}$ & $\begin{array}{l}8.19 d \\
2.43 e \\
2.82 e \\
1.97 e\end{array}$ & $\begin{array}{l}126.12 \mathrm{c} \\
25.44 d \\
42.86 \mathrm{~cd} \\
19.24 \mathrm{e}\end{array}$ & $\begin{array}{l}24.01 b \\
4.99 \mathrm{~cd} \\
11.09 \mathrm{c} \\
2.69 \mathrm{~d}\end{array}$ \\
\hline
\end{tabular}

$\dagger$ In each column, in each manure type, values followed by the same letter are not significantly different as determined by the least square means test $(P \leq \mathbf{0 . 0 5}), n=16$. 
Table 3. Efficacy of polyacrylamide (PAM), PAM + Al (SO $)_{3}$, and PAM + CaO to remove total coliform bacteria, fecal coliform bacteria, and fecal streptococci from water flowing at $8.6 \mathrm{~L} \mathrm{~min}$ mev $^{-1}$ ov 6 of dairy manure. $\dagger$

\begin{tabular}{|c|c|c|c|c|c|c|c|}
\hline Manure & Treatment & Distance $\ddagger$ & Total coliforms & Fecal coliforms & Fecal streptococci & Active bacteria & Active fungi \\
\hline \multirow{4}{*}{$\begin{array}{l}\text { Cattle } \\
\text { Cattle }\end{array}$} & \multirow{3}{*}{$\begin{array}{l}\text { source material } \\
\text { control }\end{array}$} & \multirow[t]{2}{*}{$\mathbf{m}$} & \multicolumn{3}{|c|}{$\ldots$} & \multicolumn{2}{|c|}{$\longrightarrow \mu_{\mathrm{g}} \mathrm{C} \mathrm{mL} \mathrm{L}^{-1}$} \\
\hline & & & $1.87 \times 10^{7} \mathrm{a}$ & $5.00 \times 10 \mathrm{a}$ & $8.23 \times 10^{s} \mathrm{a}$ & $64.63 \mathrm{a}$ & $268.07 a$ \\
\hline & & inflow & $1.74 \times 10^{4} \mathrm{~d}$ & $0.00 \mathrm{e}$ & $37 \mathbf{e}$ & $5.83 \mathrm{c}$ & 0.00d \\
\hline & $\begin{array}{l}\text { PAM } \\
\mathbf{P A M}+\mathbf{A I}\left(\mathrm{SO}_{4}\right)_{3} \\
\mathbf{P A M}+\mathbf{C a O}\end{array}$ & & $\begin{array}{l}1.64 \times 10^{4} d \\
1.64 \times 10^{4} d \\
1.56 \times 10^{d} d\end{array}$ & $\begin{array}{l}0.00 \mathrm{e} \\
0.00 \mathrm{ke} \\
0.00 \mathrm{e}\end{array}$ & $\begin{array}{l}\text { 1.00e } \\
2.00 \mathrm{e} \\
\text { 0.00e }\end{array}$ & $\begin{array}{l}5.41 c \\
6.82 c \\
6.34 c\end{array}$ & $\begin{array}{l}\text { o.c0d } \\
\text { 0.00d } \\
\text { 0.00d }\end{array}$ \\
\hline \multirow[t]{2}{*}{ Cattle } & control & 1.0 & $2.64 \times 10^{5} \mathrm{~b}$ & $3.92 \times 10^{3} \mathrm{~b}$ & $9.50 \times 10^{3} \mathrm{~d}$ & $10.35 b$ & $106.00 b$ \\
\hline & $\begin{array}{l}\mathbf{P A M} \\
\mathbf{P A M}+\mathbf{A I}\left(\mathrm{SO}_{4}\right)_{3} \\
\mathbf{P A M}+\mathbf{C a O}\end{array}$ & & $\begin{array}{l}1.44 \times 10^{4} \mathrm{c} \\
1.11 \times 10^{4} \mathrm{c} \\
1.22 \times 10^{4} \mathrm{c}\end{array}$ & $\begin{array}{l}6.20 \times 10^{1} d \\
7.77 \times 10^{1} d \\
3.51 \times 10^{1} d\end{array}$ & $\begin{array}{l}3.44 \times 10^{2} d \\
3.02 \times 10^{2} d \\
8.85 \times 10^{2} d\end{array}$ & $\begin{array}{l}5.14 c \\
6.55 c \\
5.25 c\end{array}$ & $\begin{array}{l}0.00 d \\
4.93 c \\
0.00 d\end{array}$ \\
\hline \multirow[t]{2}{*}{ Cattle } & control & 27.0 & $2.99 \times 10^{5 b}$ & $9.46 \times 10^{3} \mathrm{~b}$ & $2.22 \times 10^{4} \mathrm{~b}$ & $9.39 \mathrm{~b}$ & $0.00 d$ \\
\hline & $\begin{array}{l}\mathbf{P A M} \\
\mathbf{P A M}+\mathbf{A l}\left(\mathrm{SO}_{4}\right)_{3} \\
\mathbf{P A M}+\mathbf{C g O}\end{array}$ & & $\begin{array}{l}1.13 \times 10 \mathrm{c} \\
1.07 \times 10 \% \mathrm{c} \\
8.52 \times 10 \mathrm{bc}\end{array}$ & $\begin{array}{l}2.12 \times 10^{2} c \\
6.08 \times 10^{2} c \\
5.67 \times 10^{2} c\end{array}$ & $\begin{array}{l}1.06 \times 10^{3} \mathrm{c} \\
1.20 \times 10^{3} \mathrm{c} \\
5.59 \times 10^{3} \mathrm{c}\end{array}$ & $\begin{array}{l}5.92 c \\
5.57 c \\
5.25 c\end{array}$ & $\begin{array}{l}4.93 c \\
9.87 c \\
0.00 d\end{array}$ \\
\hline
\end{tabular}

$\dagger$ In each column, values followed by the same letter are not significantly difierent as determined by the least square means test $(P \leq 0.05), n=27$.

$\ddagger$ Distance from treatment. Infow water was sampled prior to fowing over animal waste.

and nutrients that could be loosely held to sand particles. Columns were allowed to drain for $1 \mathrm{~h}$ prior to the start of the experiment. One-centimeter-thick PAM $+\mathrm{Al}\left(\mathrm{SO}_{4}\right)_{3}$ or PAM + $\mathrm{CaO}$ mixtures were spread on the surface of each sand column. A solid wet cattle, fish, or swine waste $2.5 \mathrm{~cm}$ thick was placed over the control, PAM, PAM $+\mathrm{Al}\left(\mathrm{SO}_{4}\right)_{3}$, or PAM + $\mathrm{CaO}$ mixtures. A $6.5-\mathrm{cm}$ head space at the top of each column was left so that distilled water could be poured over the animal waste. A $15.24-\mathrm{cm}$-diameter funnel was placed under each column and into a 500-mL erlenmeyer flask below (Fig. 1).

\section{Polyacrylamide}

The PAM copolymer used was a dry granular material having an approximate molecular weight of 12 to $15 \mathrm{Mg} \mathrm{mol}^{-1}$, with an $18 \%$ negative charge density (provided by CYTEC Industries [Wayne, $\mathrm{NJ}$ ] and marketed under the trade name Superfloc 836A).

\section{Treatments}

Polyacrylamide treatments consisted of $5 \mathrm{~g}$ of PAM, $10 \mathrm{~g}$ $\mathrm{PAM}+\mathrm{Al}\left(\mathrm{SO}_{4}\right)_{3}\left[5 \mathrm{~g}\right.$ PAM mixed with $\left.5 \mathrm{~g} \mathrm{Al}\left(\mathrm{SO}_{4}\right)_{3}\right]$, or $10 \mathrm{~g}$ $\mathrm{PAM}+\mathrm{CaO}(5 \mathrm{~g}$ PAM mixed with $5 \mathrm{~g} \mathrm{CaO})$ spread over the surface of sand surface. Then $100 \mathrm{~mL}$ of solid wet animal waste was poured over the various PAM treatments (Fig. 1). The control treatment did not have a PAM mixture placed on the sand surface. After animal waste was applied over the PAM mixtures, $500 \mathrm{~mL}$ distilled water was poured over the top of the animal waste. Water flowed through the animal waste, through the PAM mixtures, and finally through washed sand. Leachate was collected in a $500-\mathrm{mL}$ erlenmeyer flask (Fig. 1). The PAM-only treatment consisted of a layer of $5 \mathrm{~g}$ PAM spread over the surface of the sand in the $10-\mathrm{cm}$ diameter (Fig. 1). The PAM $+\mathrm{Al}\left(\mathrm{SO}_{4}\right)_{3}$ treatment consisted of a mixture of $5 \mathrm{~g}$ PAM mixed with $5 \mathrm{~g} \mathrm{Al}\left(\mathrm{SO}_{4}\right)_{3}$ spread over the surface of the sand, and the PAM + $\mathrm{CaO}$ treatment consisted of $5 \mathrm{~g}$ PAM mixed with $5 \mathrm{~g} \mathrm{CaO}$. After the above described PAM treatments were applied to the surface of the sand in each column, $100 \mathrm{~mL}$ of cattle, fish, or swine manure was placed on top of each treatment (Fig. 1.) Five hundred milliliters of distilled water was then applied to each column. Columns were allowed to drain until leachate filled the $500-\mathrm{mL}$ erlenmeyer flask below each column $(2-4 \mathrm{~h})$. Survival of total and fecal coliform bacteria, fecal streptococci bacteria, active and total fungi and bacteria, and nutrients contained in leachate from each column were analyzed as described below.

\section{Surface Flow Field Study}

\section{Field Study Site}

The study was conducted at the USDA Agricultural Research Service's Northwest Irrigation and Soils Research Laboratory in Kimberly, ID. The soil in the test field was Portneuf

Table 4. Efficacy of polyacrylamide (PAM), PAM + Al (SOA), and PAM + CaO to remove total coliform bacteria, fecal coliform bacteria, and fecal streptococei from water fowing at $8.6 \mathrm{~L} \mathrm{~min}$ mer $^{-1}$ ov $\mathrm{L}$ of fish manure. $\dagger$

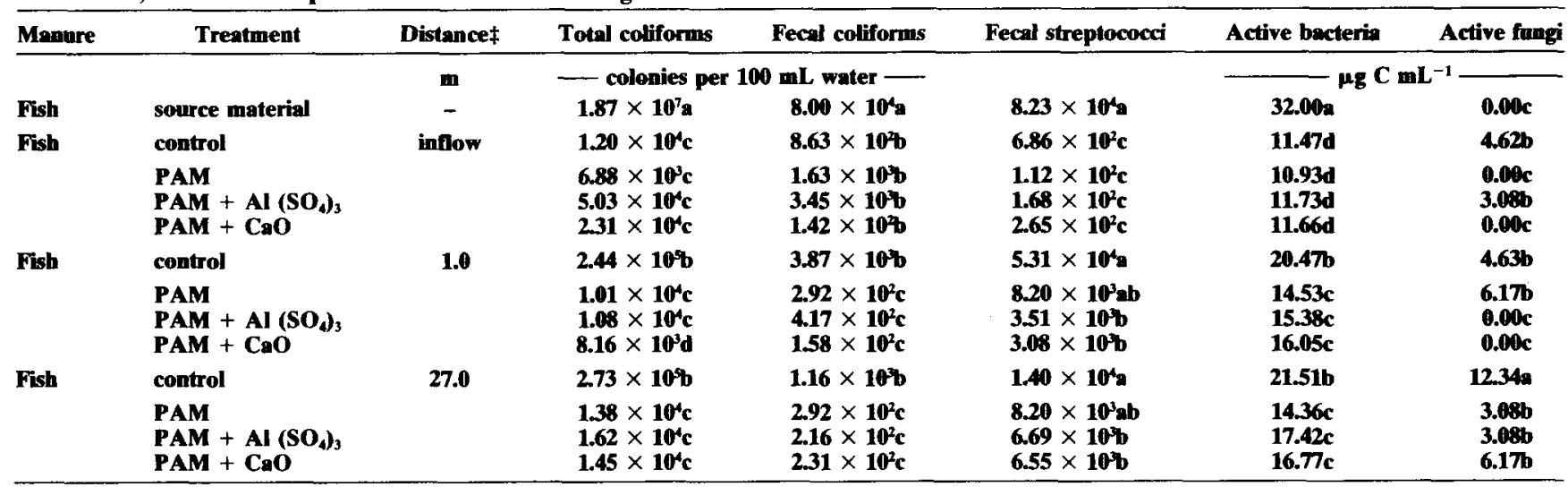

† In each column, values followed by the same letter are not significantly different as determined by the least square means test $(P \leq 0.05), n=27$. $¥$ Distance from treatment. Inflow water was sampled prior to flowing over animal waste. 
Table 5. Efficacy of polyacrylamide (PAM), PAM $+\mathrm{Al}\left(\mathrm{SO}_{4}\right)_{3}$, and PAM $+\mathrm{CaO}$ to remove total coliform bacteria, fecal coliform bacteria, and fecal streptococci from water flowing at $8.6 \mathrm{~L} \mathrm{~min}$ mever $^{-1} .6 \mathrm{~L} \mathrm{of} \mathrm{hog} \mathrm{manure.} \dagger$

\begin{tabular}{|c|c|c|c|c|c|c|c|}
\hline Manure & Treatment & Distance $\ddagger$ & Total coliforms & Fecal coliforms & Fecal streptococci & Active bacteria & Active fun \\
\hline & & m & 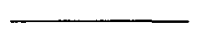 & onies per $160 \mathrm{~mL}$ & ter - & $-\mu \mathrm{g} C$ & -1 \\
\hline \multirow{3}{*}{$\begin{array}{l}\text { Swine } \\
\text { Swine }\end{array}$} & source material & - & $3.80 \times 10^{6 \mathrm{a}}$ & $4.53 \times 10^{4} \mathrm{a}$ & $1.10 \times 10^{5}$ & $48.86 \mathrm{a}$ & $28.72 c$ \\
\hline & control & inflow & $9.80 \times 10^{5} \mathrm{~b}$ & $6.90 \times 10^{3} \mathrm{ab}$ & $1.80 \times 10^{3} c$ & $12.64 c$ & $0.00 \mathrm{f}$ \\
\hline & $\begin{array}{l}\text { PAM } \\
\text { PAM }+\mathbf{A l}\left(\mathrm{SO}_{4}\right)_{3} \\
\text { PAM }+\mathrm{CaO}\end{array}$ & & $\begin{array}{l}7.35 \times 10^{8 b} \\
1.04 \times 10^{6} \mathrm{ab} \\
5.16 \times 10^{5} \mathrm{~b}\end{array}$ & $\begin{array}{l}1.82 \times 10^{2} \mathrm{~b} \\
8.12 \times 10^{2} \mathrm{~b} \\
2.00 \times 10^{4} \mathrm{a}\end{array}$ & $\begin{array}{l}6.03 \times 10^{3} c \\
2.00 \times 10^{3} c \\
4.15 \times 10^{3} c\end{array}$ & $\begin{array}{l}13.16 c \\
13.99 c \\
11.69 c\end{array}$ & $\begin{array}{l}9.34 \mathrm{e} \\
0.00 f \\
0.006\end{array}$ \\
\hline \multirow[t]{2}{*}{ Swine } & control & 1.0 & $1.84 \times 10^{6} \mathrm{a}$ & $1.36 \times 10^{4}$ & $1.24 \times 10 \%$ & $21.30 \mathrm{~b}$ & 18.68d \\
\hline & $\begin{array}{l}\text { PAM } \\
\text { PAM }+\mathbf{A I}\left(\mathrm{SO}_{4}\right)_{3} \\
\text { PAM }+\mathrm{CaO}\end{array}$ & & $\begin{array}{l}7.85 \times 10 \mathrm{~b} \\
1.55 \times 10^{\circ} \mathrm{b} \\
1.28 \times 10 \mathrm{~b}\end{array}$ & $\begin{array}{l}1.06 \times 10^{3} \mathrm{~b} \\
3.34 \times 10^{3} \mathrm{~b} \\
7.02 \times 10^{2} \mathrm{c}\end{array}$ & $\begin{array}{l}4.90 \times 10^{3} \mathrm{c} \\
2.75 \times 10^{3} \mathrm{c} \\
2.17 \times 10^{3} \mathrm{c}\end{array}$ & $\begin{array}{l}18.57 \mathrm{~b} \\
12.63 \mathrm{c} \\
12.72 \mathrm{c}\end{array}$ & $\begin{array}{r}266.19 \mathrm{a} \\
121.42 \mathrm{~b} \\
32.69 \mathrm{c}\end{array}$ \\
\hline \multirow[t]{2}{*}{ Swine } & control & 27.0 & $9.90 \times 10^{5} \mathrm{a}$ & $4.24 \times 10^{4} \mathrm{a}$ & $1.73 \times 10 \mathrm{~b}$ & $26.98 \mathrm{~b}$ & 3.11e \\
\hline & $\begin{array}{l}\text { PAM } \\
\text { PAM }+ \text { Al }\left(\mathrm{SO}_{4}\right)_{3} \\
\text { PAM }+\mathbf{C a O}^{2}\end{array}$ & & $\begin{array}{l}2.95 \times 10^{5} \mathrm{~b} \\
4.07 \times 10^{5} \mathrm{ab} \\
4.90 \times 10^{5} \mathrm{~b}\end{array}$ & $\begin{array}{l}3.71 \times 10^{2} \mathrm{~b} \\
2.06 \times 10^{2} \mathrm{~b} \\
1.41 \times 10^{2} \mathrm{~b}\end{array}$ & $\begin{array}{l}5.96 \times 10^{3} \mathrm{c} \\
1.03 \times 10^{3} \mathrm{c} \\
1.01 \times 10^{3} \mathrm{c}\end{array}$ & $\begin{array}{l}13.98 c \\
13.9 .1 c \\
13.28 c\end{array}$ & $\begin{array}{l}90.41 b \\
60.43 c \\
23.35 d\end{array}$ \\
\hline
\end{tabular}

$\dagger$ In each column, values followed by the same letter are not significantly different as determined by the least square means test $(P \leq 0.05), n=27$.

$\ddagger$ Distance from treatment. Inflow waste was sampled prior to fowing over animal waste.

silt loam (coarse-silty, mixed, superactive, mesic Durinodic Xeric Haplocalcid), with 10 to $21 \%$ clay and 60 to $75 \%$ silt, and organic matter of approximately $13 \mathrm{~g} \mathrm{~kg}^{-1}$. Saturated paste extract electrical conductivity (EC) of this soil ranges from 0.7 to $1.3 \mathrm{dS} \mathrm{m}^{-1}$, with exchangeable sodium percentage (ESP) of 1.4 to $1.7, \mathrm{pH}$ of 7.6 to 8.0 , and a $\mathrm{CaCO}_{3}$ equivalent of 2 to $8 \%$. Slope on this site was approximately $1.5 \%$.

\section{Experimental Design}

The surface flow study was also arranged in a completely random design consisting of four remediation treatments: (i) $\mathrm{PAM}$, (ii) $\mathrm{PAM}+\mathrm{Al}\left(\mathrm{SO}_{4}\right)_{3}$, (iii) $\mathrm{PAM}+\mathrm{CaO}$, and (iv) control (no treatment). Each remediation treatment had three different manure types superimposed (cattle, fish, and swine) corresponding to three different dates (Kirk, 1982). Cattle manure was used as a waste source on 24 Aug. 1998, fish manure was used as a waste source on 8 Sept. 1998, and swine manure was used a waste source on 16 Sept. 1998. Surface flow was sampled at three distances along the furrows (at the inflow point and at 1 and $27 \mathrm{~m}$ down slope of the above treatments; Fig. 2) and at three times during flow $(0.5,3.5$, and $6.5 \mathrm{~h})$. We analyzed three subsamples for each microbial and nutrient parameter (stated below) from each sample to account for sampling error (Kirk, 1982). We took 324 samples for the study (four treatments $\times$ three manure types $\times$ three sampling points along each furrow $\times$ three sampling times during each water application $\times$ three samples from each water collection as sampling error).

\section{Treatment Application}

Furrows were prepared with weighted $75^{\circ}$ shaping tools. Furrows were $0.1 \mathrm{~m}$ wide $\times 0.1 \mathrm{~m}$ deep $\times 30 \mathrm{~m}$ long. We placed $9.5 \mathrm{~L}$ of solid wet cattle, fish, or swine waste $0.3 \mathrm{~m}$ from the water inflow point in a 1.0 -m-long area (Fig. 2). Immediately downstream PAM or PAM mixtures were placed in a $1.0-\mathrm{m}$ long-area (Fig. 2). Water flowed $0.3 \mathrm{~m}$ from the inflow point and then flowed over a $0.1-\mathrm{m}$-wide $\times 0.1$ m-deep $\times 1.0$-m-long area containing $9.5 \mathrm{~L}$ of solid wet cattle, fish, or swine manure and then over a $0.1-\mathrm{m}$-wide $\times 0.1-\mathrm{m}$ deep $\times 1.0$-m-long area containing the PAM, PAM + $\mathrm{Al}\left(\mathrm{SO}_{4}\right)_{3}$, and PAM $+\mathrm{CaO}$ mixtures or no chemical (control) treatment (Fig. 1). Application of PAM, PAM $+\mathrm{Al}\left(\mathrm{SO}_{4}\right)_{3}$, and PAM + $\mathrm{CaO}$ involved the spread of granular PAM on the surface of the soil. Application amounts were $35 \mathrm{~g}$ PAM, a mixture of $35 \mathrm{~g}$ PAM $+350 \mathrm{~g} \mathrm{Al}\left(\mathrm{SO}_{4}\right)_{3}$, and a mixture of $35 \mathrm{~g}$ PAM $+350 \mathrm{~g} \mathrm{CaO}$. Irrigation water came from the Snake River via Twin Falls Canal Company, through a storage pond to 10 -cm-wide $\times 10$-cm-deep $\times 40$-m-long furrows at a rate of $7.6 \mathrm{~L} \mathrm{~min} \mathrm{~min}^{-1}$ in spigoted plastic pipe. Experience from other experiments has shown that water flowing over these patches of PAM granules results in PAM concentrations of 5 to $15 \mathrm{~g}$ $\mathrm{m}^{-3}$ during the first 20 to $40 \mathrm{~min}$ during the flow of water,

Table 6. Efficacy of polyacrylamide (PAM), PAM $+\mathrm{Al}\left(\mathrm{SO}_{4}\right)_{3}$, and PAM $+\mathrm{CaO}$ to filter nutrients in cattle wastewater flowing at 8.6 $\mathrm{L} \mathrm{min}^{-1}$ over $8.6 \mathrm{~L}$ of manure.

\begin{tabular}{|c|c|c|c|c|c|c|c|c|c|}
\hline Manure & Treatment & Distance $\ddagger$ & PO. & Total P & $\mathrm{NO}_{3}$ & NH4 & $\mathbf{K}$ & Ca & $\mathbf{M g}$ \\
\hline & & $\mathbf{m}$ & & & $-\mu \mathrm{g}$ e & mt per mI & ter - & & \\
\hline & source material & infow & $1596.00 \mathrm{a}$ & $2630.00 a$ & $104.83 a$ & $490.07 \mathrm{a}$ & $1630.00 \mathrm{a}$ & 711.70 & 1981.00 \\
\hline \multirow[t]{4}{*}{ Cattle } & control & & $0.025 \mathrm{c}$ & $1.72 e$ & $0.23 c$ & $0.08 d$ & $2.11 c$ & 20.876 & $4.42 \mathrm{~b}$ \\
\hline & control & 1.0 & $0.50 \mathrm{~b}$ & $16.01 b$ & $0.44 c$ & $0.34 \mathrm{~b}$ & $5.66 \mathrm{c}$ & $15.78 b$ & $5.66 \mathrm{~b}$ \\
\hline & control & 27.0 & $0.21 \mathrm{c}$ & $10.49 \mathrm{c}$ & $0.93 b$ & $0.07 d$ & $4.06 \mathrm{c}$ & $16.21 b$ & $3.7 m$ \\
\hline & $\begin{array}{l}\text { PAM } \\
\text { PAM }+\mathrm{Al}_{\left(\mathrm{SO}_{4}\right)_{3}} \\
\mathbf{P A M}+\mathrm{CaO}\end{array}$ & & $\begin{array}{l}0.27 c \\
0.07 d \\
0.11 d\end{array}$ & $\begin{array}{l}11.07 \mathrm{c} \\
5.31 d \\
8.71 \mathrm{~cd}\end{array}$ & $\begin{array}{l}1.28 b \\
0.72 b \\
0.89 b\end{array}$ & $\begin{array}{l}0.20 c \\
0.14 c \\
0.15 c\end{array}$ & $\begin{array}{l}3.78 c \\
3.82 c \\
4.66 c\end{array}$ & $\begin{array}{l}16.92 b \\
16.14 b \\
16.35 b\end{array}$ & $\begin{array}{l}5.08 \mathrm{~b} \\
3.70 \mathrm{~b} \\
\mathbf{3 . 7 4 b}\end{array}$ \\
\hline
\end{tabular}

$\dagger$ In each column, values followed by the same letter are not significantly different as determined by the least square means test $(P \leq 0.05), n=27$. $¥$ Distance from treatment. 
declining to much lower concentrations after $6 \mathrm{~h}$ (Sojka, unpublished data, 1999).

\section{Microbial Sample Collection}

Three separate water samples were collected from the surface to a $3.0-\mathrm{cm}$ depth at the inflow point, $1 \mathrm{~m}$ and $27 \mathrm{~m}$ below the PAM, PAM $+\mathrm{Al}\left(\mathrm{SO}_{4}\right)_{3}$, and PAM $+\mathrm{CaO}$ treatments. Samples were collected $0.5,3.5$, and $6.5 \mathrm{~h}$ after water flow was initiated. Samples were analyzed for total coliform bacteria, fecal coliform bacteria, fecal streptococci, active and total fungi and bacteria, $\mathrm{NO}_{3}, \mathrm{NH}_{4}, \mathrm{PO}_{4}$, total $\mathrm{P}, \mathrm{K}, \mathrm{Ca}$, and $\mathrm{Mg}$. Water was collected and stored in air-tight and water-tight 125 -mL glass bottles and prepared for coliform testing within $2 \mathrm{~h}$ of collection (Greenberg et al., 1992). Water samples tested for active bacteria and fungi were stored at $4^{\circ} \mathrm{C}$ and analyzed within $24 \mathrm{~h}$ of collection (West et al., 1986) to minimize the effects of storage on microbial activity. Subsamples tested for nutrients were stored at $4^{\circ} \mathrm{C}$ prior to testing.

\section{Coliform Procedures}

Total coliform, fecal coliform, and fecal streptococcal bacteria were analyzed using the membrane filter technique (Greenberg et al., 1992). Preliminary water samples from test runs taken 1 to $3 \mathrm{~d}$ prior to each test were analyzed to determine each dilution before bacteria were counted. One gram of water was diluted in a series of 2 to 5 . One hundred milliliters of final dilution of each sample was vacuum-filtered through a sterile $0.45-\mu \mathrm{m}$ filter and placed on Em endo medium to determine total coliform bacteria, FC medium to determine fecal coliform bacteria, and KF streptococcus medium to determine fecal streptococci. Total coliform bacteria and fecal streptococci were incubated at $39.5 \pm 0.02^{\circ} \mathrm{C}$. Fecal coliform bacteria were incubated at $44.5 \pm 0.02^{\circ} \mathrm{C}$ for $24 \mathrm{~h}$.

\section{Microbial Biomass Measurements}

Active and total bacteria and fungi in leachate and surface flow were determined for each treatment using methods described by Ingham and Klein (1984). Active fungi were estimated by taking a $1.0-\mathrm{mL}$ water sample diluted in $9 \mathrm{~mL}$ of a phosphate buffer ( $\mathrm{pH} \mathrm{6.0)}$ ) and shaken at approximately 120 $\mathrm{rpm}$ for $5 \mathrm{~min}$. A $1-\mathrm{mL}$ aliquot was removed and stained with $1 \mathrm{~mL}$ of a $20 \mu \mathrm{g} \mathrm{mL}^{-1}$ fluorescein diacetate (FDA) solution in a $0.2 M$ phosphate buffer ( $\mathrm{pH} 7.0$ ) for $3 \mathrm{~min}$. One milliliter of $1.5 \%$ agar in a $0.1 M$ phosphate buffer ( $\mathrm{pH} 9.5$ ) was added to the FDA suspension. The sample was mixed and an aliquot placed on a microscope slide containing a cavity of known volume (Ingham and Klein, 1984). Immediately after preparation, slides were examined for FDA-stained hyphal length by

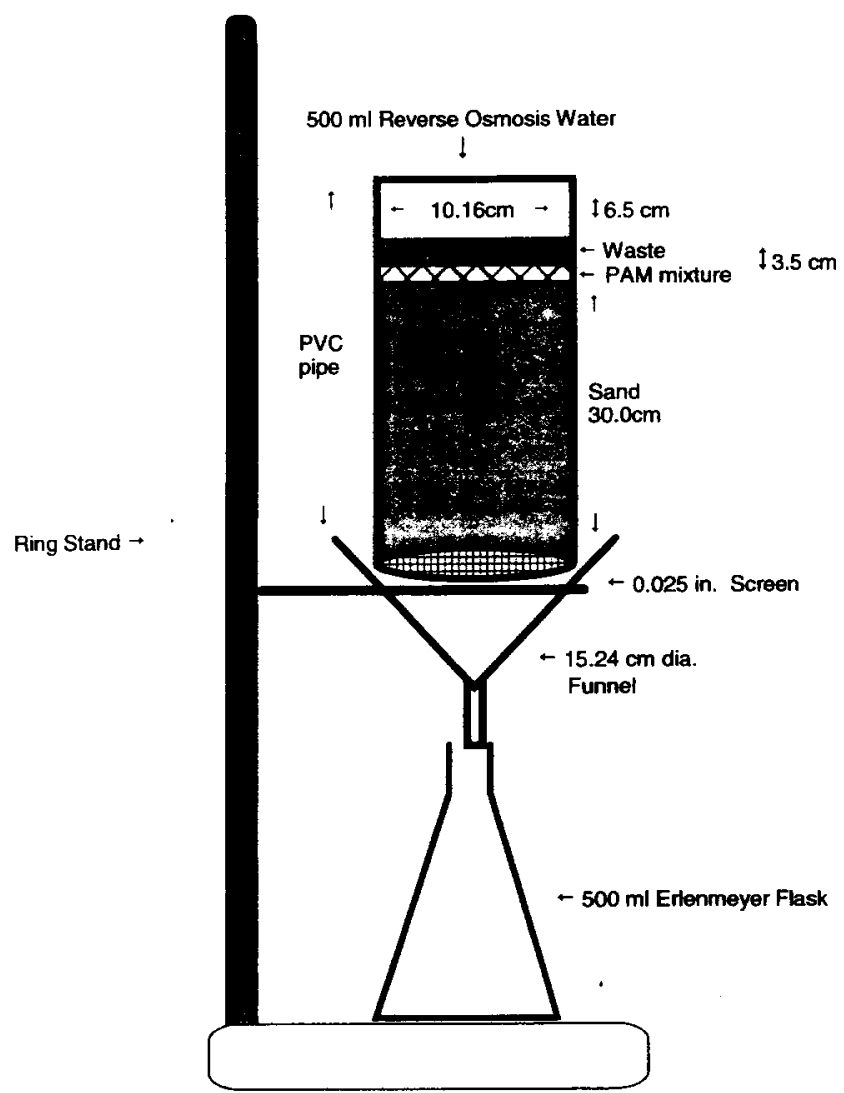

Fig. 1. Diagram of column apparatus showing distilled water poured over animal waste that overlies the polyacrylamide treatment draining through washed sand into an erlenmeyer flask.

epifluorescent microscopy. Total fungal biomass was estimated by measuring the length and diameter of hyphae in 3 to 60 fields with phase-contrast microscopy. Three slides were evaluated from each sample and 10 fields per slide were evaluated with phase contrast microscopy for total hyphal length. Three transects were evaluated for FDA-stained (active) hyphal length at $160 \times$ total magnification.

Iodonitrotetrazolium (INT) stain was used for counting active bacteria (Stamatiadis et al., 1990). A 1-mL sample of initial soil suspension was diluted to a final dilution in a mixture of $0.2 \mathrm{mg}$ soil and $4 \mathrm{~mL}$ buffer. The suspension was incubated with $4 \mathrm{~mL}$ of filtered INT buffer for $60 \mathrm{~min}$ in the dark at $20^{\circ} \mathrm{C}$. Total bacteria per milliliter of water were estimated from the mean number of bacteria (fluorescent and nonfluorescent

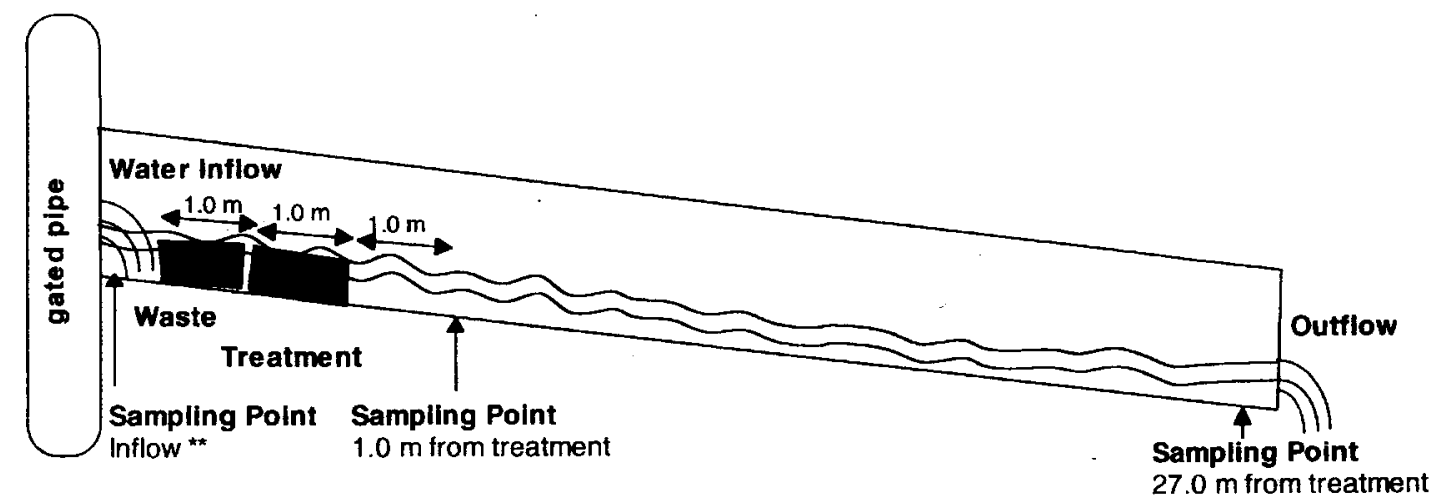

Fig. 2. Diagram of rill showing irrigation water flowing over manure then a polyacrylamide treatment and collection points at 1 and $27 \mathrm{~m}$ from treatments. 
bacteria), their average diameter, and length per field. Three slides were evaluated for each sample and 10 fields per slide were evaluated using epifluorescent oil-immersion microscopy to determine numbers and size of fluorescent and total bacteria (Lodge and Ingham, 1991). Bacterial volume was computed from the number of soil bacteria per gram of soil considering that bacterial spheres were $1 \mu \mathrm{m}$ in diameter (Jenkinson and Ladd, 1981). A carbon to volume conversion factor of $120 \mu \mathrm{g}$ $\mathrm{C} \mathrm{mm^{-3 }}$ was used for both bacteria and fungi, assuming $1.1 \mathrm{~g}$ $\mathrm{cm}^{-3}$ wet density, $20 \%$ dry matter content, and a $0.41 \mathrm{~g} \mathrm{~g}^{-1}$ carbon content in the bacterium or fungus (Jenkinson and Ladd, 1981).

\section{Soil Chemical Analysis}

Nitrate and ammonium were determined using a Lachat autoanalyzer (Lachat Quickchem Systems, Milwaukee, WI) using methods described in Keeney and Nelson (1982). Phosphate and total $P$ were determined using methods described in Olsen and Sommers (1982). Potassium, Ca, and Mg were determined using an atomic absorption spectrometer.

\section{Statistical Analyses}

All dependent variables were tested for normal distribution. Number of total and fecal coliform bacteria were transformed using logarithms to achieve normal distributions. Data were then analyzed using general linear models (GLM) procedures for a completely random design with Statistical Analysis Systems (SAS Institute, 1996). For the column study, statistical comparisons were made of total coliform bacteria, fecal coliform bacteria, fecal streptococci, active and total bacteria and fungi, $\mathrm{NH}_{4}^{+}, \mathrm{NO}_{3}^{-}$, total $\mathrm{P}, \mathrm{PO}_{4}^{-3}, \mathrm{~K}, \mathrm{Ca}$, and $\mathrm{Mg}$ in water by PAM mixtures $\times$ manure type because the interaction was significant in nearly all of the GLM models. In the surface flow study, statistical comparisons were made for total coliform bacteria, fecal coliform bacteria, fecal streptococci, active and total bacteria and fungi, $\mathrm{NH}_{4}^{+}, \mathrm{NO}_{3}^{-}$, total $\mathrm{P}, \mathrm{PO}_{4}^{-3}, \mathrm{~K}, \mathrm{Ca}$, and $\mathrm{Mg}$ by PAM mixtures $\times$ manure type $\times$ distance from inflow because GLM models showed these interactions were significant at $p \leq 0.05$ (Snedecor and Cochran, 1980; Kirk, 1982). In all analyses, residuals were equally distributed with constant variances. Differences reported throughout are significant at $p \leq 0.05$, as determined by the Least Squares Means test. Total coliform, fecal coliform, and fecal streptococci bacteria are reported in untransformed numbers.

\section{RESULTS}

Numbers of both total coliform, fecal coliform, and fecal streptococci were usually 10 -fold higher in source waste than the control treatments in both the column and surface flow study due to dilution by the addition of deionized or irrigation water (Tables $1,3,4$, and 5). The concentration of measured nutrients was several orders of magnitude higher in source waste than the control treatments in the column and surface flow study (Tables 2 and 6, 7, and 8, respectively).

\section{Column Study}

Columns filled with sand reduced populations of total and fecal coliform bacteria and fecal streptococci in leachate by approximately 10 -fold ( $90 \%$ reduction) in all three manure sources compared with the source manure (Table 1). The PAM, PAM $+\mathrm{Al}\left(\mathrm{SO}_{4}\right)_{3}$, and $\mathrm{PAM}+\mathrm{CaO}$ treatments reduced populations of total and fecal coliform bacteria and fecal streptococci in leachate from 10 - to 1000 -fold ( 90 to $99.9 \%$ reduction) in all three manure sources compared with the control treatment and from 100 - to 10000 -fold (90 to $99.99 \%$ reduction) compared with the source manure. The $\mathrm{PAM}, \mathrm{PAM}+\mathrm{Al}\left(\mathrm{SO}_{4}\right)_{3}$, and PAM + CaO treatments reduced the numbers of active and total bacteria and active and total fungi in leachate compared with the control treatment. The PAM $+\mathrm{Al}\left(\mathrm{SO}_{4}\right)_{3}$ and PAM + $\mathrm{CaO}$ treatments reduced the concentration of active bacteria in leachate when cattle and swine manure, but not fish manure, was applied to sand columns.

The PAM, PAM + Al( $\left(\mathrm{SO}_{4}\right)_{3}$, and PAM + CaO treatments reduced $\mathrm{NH}_{4}^{+}$, total $\mathrm{P}, \mathrm{PO}_{4}^{-3}, \mathrm{~K}, \mathrm{Ca}$, and $\mathrm{Mg}$ concentrations in leachate when cattle and swine manure, but not fish manure, was applied to sand columns (Table 2). When cattle manure was applied, the PAM + $\mathrm{Al}\left(\mathrm{SO}_{4}\right)_{3}$ and $\mathrm{PAM}+\mathrm{CaO}$ treatments reduced $\mathrm{PO}_{4}^{-3}$, $\mathrm{K}, \mathrm{Ca}$, and $\mathrm{Mg}$ concentrations in leachate compared with the PAM-only treatment. When swine manure was applied, the PAM + $\mathrm{CaO}$ treatment reduced the concentration of $\mathrm{NO}_{3}^{-}, \mathrm{NH}_{4}^{+}, \mathrm{K}, \mathrm{Ca}$, and $\mathrm{Mg}$ in leachate

Table 7. Efficacy of polyacrylamide (PAM), PAM + Al $\left(\mathrm{SO}_{4}\right)_{3}$, and PAM + CaO to filter nutrients in fish wastewater flowing at 8.6 $\mathrm{L}$ $\min ^{-1}$ over $8.6 \mathrm{~L}$ of manure. $\dagger$

\begin{tabular}{|c|c|c|c|c|c|c|c|c|c|}
\hline Manure & Treatment & Distance $\ddagger$ & $\mathbf{P O}_{4}$ & Total P & $\mathrm{NO}_{3}$ & $\mathrm{NH}_{4}$ & $\mathbf{K}$ & Ce & $\mathbf{M g}$ \\
\hline & & $\mathbf{m}$ & & $\longrightarrow$ & $-\mu \mathrm{g}$ & element per $\mathrm{m}$. & er - & & \\
\hline & source material & inflow & $1309.60 \mathrm{a}$ & $1465.30 \mathrm{a}$ & $5.97 \mathrm{a}$ & $271.50 \mathrm{a}$ & $86.63 a$ & $1428.37 a$ & $54.68 \mathrm{a}$ \\
\hline \multirow[t]{6}{*}{ Fish } & control & & $0.01 b$ & $3.50 \mathrm{~b}$ & $0.24 \mathrm{e}$ & $0.14 e$ & $2.32 x$ & $28.28 c$ & $7.41 \mathrm{c}$ \\
\hline & $\begin{array}{l}\mathbf{P A M} \\
\mathbf{P A M}+\mathbf{A l}\left(\mathrm{SO}_{4}\right)_{3} \\
\mathbf{P A M}+\mathrm{CaO}\end{array}$ & & $\begin{array}{l}0.00 b \\
0.10 b \\
0.00 b\end{array}$ & $\begin{array}{l}1.93 \mathrm{~b} \\
2.00 \mathrm{~b} \\
2.76 \mathrm{~b}\end{array}$ & $\begin{array}{l}0.25 \mathbf{e} \\
0.23 \mathrm{e} \\
0.23 \mathrm{e}\end{array}$ & $\begin{array}{l}0.18 \mathrm{e} \\
0.19 \mathrm{e} \\
0.16 \mathrm{e}\end{array}$ & $\begin{array}{l}2.32 c \\
2.30 c \\
2.31 c\end{array}$ & $\begin{array}{l}29.16 c \\
29.13 c \\
29.30 c\end{array}$ & $\begin{array}{l}7.36 c \\
7.34 c \\
7.35 c\end{array}$ \\
\hline & control & 1.0 & $0.02 b$ & $3.22 \mathrm{~b}$ & $0.36 d$ & $0.69 \mathrm{~b}$ & $3.93 \mathrm{~b}$ & $4457 b$ & $10.70 b$ \\
\hline & $\begin{array}{l}\text { PAM } \\
\text { PAM + Al }\left(\mathrm{SO}_{4}\right)_{3} \\
\mathbf{P A M}+\mathrm{CaO}\end{array}$ & & $\begin{array}{l}0.00 b \\
0.00 b \\
0.03 b\end{array}$ & $\begin{array}{l}3.11 b \\
3.00 b \\
3.12 b\end{array}$ & $\begin{array}{l}0.44 d \\
0.43 d \\
0.33 d\end{array}$ & $\begin{array}{l}0.65 b \\
0.48 c \\
0.52 c\end{array}$ & $\begin{array}{l}3.68 b \\
3.74 b \\
3.63 b\end{array}$ & $\begin{array}{l}44.7 b \\
43.33 b \\
44.41 b\end{array}$ & $\begin{array}{l}10.61 b \\
10.52 b \\
10.44 b\end{array}$ \\
\hline & control & 27.0 & $0.03 \mathbf{b}$ & $3.46 \mathrm{~b}$ & $1.13 c$ & $0.30 \mathrm{~d}$ & $4.47 \mathrm{~b}$ & 44.59 & $10.91 \mathrm{~b}$ \\
\hline & $\begin{array}{l}\text { PAM } \\
\text { PAM }+\mathbf{A l}\left(\mathrm{SO}_{4}\right)_{3} \\
\text { PAM }+\mathbf{C a O}\end{array}$ & & $\begin{array}{l}0.02 b \\
0.02 b \\
0.03 b\end{array}$ & $\begin{array}{l}2.80 b \\
2.89 \% \\
2.89 b\end{array}$ & $\begin{array}{l}1.17 \mathrm{c} \\
0.87 \mathrm{c} \\
0.81 \mathrm{c}\end{array}$ & $\begin{array}{l}0.28 \mathrm{~d} \\
0.30 \mathrm{~d} \\
0.39 \mathrm{ed}\end{array}$ & $\begin{array}{l}4.09 b \\
4.38 b \\
4.32 b\end{array}$ & $\begin{array}{l}45.35 \mathrm{~b} \\
44.64 \mathrm{~b} \\
44.96 \mathrm{~b}\end{array}$ & $\begin{array}{l}10.87 b \\
10.86 b \\
10.69 b\end{array}$ \\
\hline
\end{tabular}

$\dagger$ In each column, values followed by the same letter are not significantly difierent as determined by the least square means test $(P \leq 0.05), n=27$. †istance from treatment. 
compared with the PAM-only and PAM $+\mathrm{Al}\left(\mathrm{SO}_{4}\right)_{3}$ treatments.

\section{Surface Flow Study}

Concentration of fecal coliform bacteria in inflow water varied and was often above concentrations approved for drinking water standards (USEPA, 1998; Greenberg et al., 1992) (Tables 3, 4, and 5). As water flowed down the furrow (control treatment), total and fecal coliform bacteria and fecal streptococci numbers were reduced by approximately 10 -fold ( $90 \%$ reduction) compared with source populations. After water flowed over all three manure sources and then PAM, PAM $+\mathrm{Al}\left(\mathrm{SO}_{4}\right)_{3}$, or PAM $+\mathrm{CaO}$, total and fecal coliform bacteria and fecal streptococci were reduced by 10 - to 1000 -fold at 1 and $27 \mathrm{~m}$ downstream of the treatments compared with the control treatment. However, there was no difference in the numbers of total and fecal coliform bacteria or fecal streptococci in water at $1 \mathrm{~m}$ downstream compared with the organisms in water $27 \mathrm{~m}$ downstream of the treatments, indicating that microorganisms were removed from water fairly rapidly.

Concentrations of $\mathrm{NH}_{4}^{+}, \mathrm{PO}_{4}^{-3}$, total $\mathrm{P}, \mathrm{K}, \mathrm{Ca}$, and $\mathrm{Mg}$ in inflow water (prior to flowing over manure) did not vary among treatments (Tables 6,7 , and 8 ). When surface water flowed over cattle manure and then PAM + $\mathrm{Al}\left(\mathrm{SO}_{4}\right)_{3}$ or $\mathrm{PAM}+\mathrm{CaO}$, concentrations of $\mathrm{PO}_{4}^{-3}$ and total $P$ in water flowing at 1 and $27 \mathrm{~m}$ downstream and $\mathrm{NH}_{4}^{+}$at $27 \mathrm{~m}$ downstream of the treatments were reduced compared with the PAM-only treatment (Table 6). When surface water flowed over fish manure and then PAM, PAM $+\mathrm{Al}\left(\mathrm{SO}_{4}\right)_{3}$, or PAM $+\mathrm{CaO}$, concentrations of $\mathrm{NH}_{4}^{+}$, total $\mathrm{P}, \mathrm{PO}_{4}^{-3}, \mathrm{~K}, \mathrm{Ca}$, and $\mathrm{Mg}$ at 1 and $27 \mathrm{~m}$ downstream of the treatments were not reduced compared with the control treatment (Table 7). When surface water flowed over swine manure the PAM + $\mathrm{Al}\left(\mathrm{SO}_{4}\right)_{3}$ or $\mathrm{PAM}+\mathrm{CaO}, \mathrm{PO}_{4}^{-3}$, total $\mathrm{P}$, and $\mathrm{NH}_{4}^{+}$concentrations in water flowing at 1 and $27 \mathrm{~m}$ downstream of the treatments were reduced compared with the PAM-only treatment (Table 8).

\section{DISCUSSION}

Contamination of surface and ground water resources by pathogenic bacteria poses a potential health hazard when animal waste is applied to agricultural lands in excess quantities. Animal manure contains many different types of organisms, some that are pathogenic to humans and animals. Large scale deposition of animal manure can result in contamination of surface and ground water and potential transfer of disease-causing enteric bacteria to animals or humans (USEPA, 1998; Mallin et al., 1997; Mawdsley et al., 1995). Despite the ability of soil to filter and kill pathogenic bacteria contained in human and animal waste, land application rates exceeding the soil's capacity to adsorb and process these materials results in contamination of water resources. Laboratory and field studies have shown that enteric microorganisms can be transported long distances through soil (Smith et al., 1985; Chen, 1988; Van Elsas et al., 1991; Huysman and Verstraete, 1993). The explanation that has been given is that preferential flow of water transports bacteria through soil macropores, cracks, and fissures (McMurry et al., 1998; Abu-Ashour et al., 1994).

The water-soluble PAMs developed for use in erosion control are very large anionic molecules that have been shown to be safe for a variety of food, pharmeceutical, and sensitive environmental applications (Barvenik, 1994). They should not be confused with gel-forming cross-linked PAM, or evaluated with other PAM formulations, especially cationic PAMs, which have known safety concerns related to their specific chemistries (Barvenik, 1994). Environmental regulation, safety, and toxicity issues related to PAM use have been extensively reviewed (Seybold, 1994; Barvenik, 1994; Deskin, 1996; Barvenik et al., 1996).

Although the precise mechanism is not fully understood, PAM compounds are used in many industrial processes to accelerate flocculation. Polyacrylamide has been used in irrigated agriculture for erosion control and increased infiltration (Aase et al., 1998; Lentz et al., 1992; Lentz and Sojka, 1994; Sojka et al., 1998a,b).

Table 8. Efficacy of polyacrylamide (PAM), PAM $+\mathrm{Al}\left(\mathrm{SO}_{4}\right)_{3}$, and PAM $+\mathrm{CaO}$ to filter nutrients in hog wastewater flowing at 8.6 $\mathrm{L}$ $\min ^{-1}$ over $8.6 \mathrm{~L}$ of manure. ${ }^{+}$

\begin{tabular}{|c|c|c|c|c|c|c|c|c|c|}
\hline Manure & Treatment & Distance $\ddagger$ & $\mathrm{PO}_{4}$ & Total P & $\mathrm{NO}_{3}$ & $\mathbf{N H}_{4}$ & $\mathbf{K}$ & Ca & $\mathbf{M g}$ \\
\hline & & $\mathbf{m}$ & & & $-\mu g \mathrm{e}$ & $t$ per $\mathrm{mL}$ & $\mathbf{r}$ & & \\
\hline & source material & inflow & $6440.53 a$ & 3359.33a & $10.17 \mathbf{a}$ & $946.05 a$ & $815.06 \mathrm{a}$ & $60.02 \mathrm{a}$ & $37.65 \mathrm{a}$ \\
\hline \multirow[t]{6}{*}{ Hog } & control & & $0.00 \mathrm{~d}$ & $0.27 \mathrm{~b}$ & $0.01 \mathrm{e}$ & $0.14 c$ & $3.21 b$ & $43.17 \mathrm{~b}$ & $11.28 b$ \\
\hline & $\begin{array}{l}\text { PAM } \\
\text { PAM }+\mathrm{Al}\left(\mathrm{SO}_{4}\right)_{3} \\
\text { PAM }+\mathrm{CaO}\end{array}$ & & $\begin{array}{l}0.01 d \\
0.06 d \\
0.00 d\end{array}$ & $\begin{array}{l}0.58 \mathrm{~b} \\
0.42 \mathrm{~b} \\
0.24 \mathrm{~b}\end{array}$ & $\begin{array}{l}0.05 e \\
0.03 e \\
0.09 e\end{array}$ & $\begin{array}{l}0.28 c \\
0.34 c \\
0.09 c\end{array}$ & $\begin{array}{l}3.20 b \\
3.22 b \\
3.20 b\end{array}$ & $\begin{array}{l}42.85 b \\
43.16 b \\
42.96 b\end{array}$ & $\begin{array}{l}11.03 b \\
11.04 b \\
11.23 b\end{array}$ \\
\hline & control & 1.0 & $0.22 b$ & $0.00 \mathrm{c}$ & $0.59 b c$ & $0.36 c$ & $4.56 \mathrm{~b}$ & $43.50 \mathrm{~b}$ & $11.56 \mathrm{~b}$ \\
\hline & $\begin{array}{l}\text { PAM } \\
\text { PAM }+\mathbf{A l}\left(\mathrm{SO}_{4}\right)_{3} \\
\text { PAM }+\mathrm{CaO}\end{array}$ & & $\begin{array}{l}0.18 c \\
0.01 d \\
0.02 d\end{array}$ & $\begin{array}{l}0.13 c \\
0.12 c \\
0.00 c\end{array}$ & $\begin{array}{l}0.5 \mathrm{dbc} \\
0.25 \mathrm{~d} \\
0.23 \mathrm{~d}\end{array}$ & $\begin{array}{l}0.52 c \\
1.23 b \\
0.5 b\end{array}$ & $\begin{array}{l}4.26 b \\
5.16 b \\
4.32 b\end{array}$ & $\begin{array}{l}44.03 b \\
46.71 b \\
43.48 b\end{array}$ & $\begin{array}{l}11.44 b \\
11.78 b \\
11.26 h\end{array}$ \\
\hline & control & 27.0 & $0.13 b$ & $0.00 c$ & $0.47 \mathrm{bc}$ & $0.31 c$ & $4.97 \mathrm{~b}$ & $44.55 b$ & $11.14 b$ \\
\hline & $\begin{array}{l}\text { PAM } \\
\text { PAM + Al }\left(\mathbf{S O}_{4}\right)_{3} \\
\text { PAM }+\mathbf{C a O}\end{array}$ & & $\begin{array}{l}0.08 c \\
0.04 d \\
0.06 d\end{array}$ & $\begin{array}{l}0.00 c \\
0.00 c \\
0.00 c\end{array}$ & $\begin{array}{l}0.72 b \\
0.43 c \\
0.83 c\end{array}$ & $\begin{array}{l}0.30 \mathrm{c} \\
0.50 \mathrm{c} \\
0.53 \mathrm{c}\end{array}$ & $\begin{array}{l}4.18 \mathrm{~b} \\
5.20 \mathrm{~b} \\
5.67 \mathrm{~b}\end{array}$ & $\begin{array}{l}44.38 b \\
45.29 b \\
44.12 b\end{array}$ & $\begin{array}{l}10.77 \mathrm{~b} \\
10.98 \mathrm{~b} \\
10.57 \mathrm{~b}\end{array}$ \\
\hline
\end{tabular}

+ In each column, values followed by the same letter are not significantly different as determined by the least square means test $(P \leq 0.05), n=27$. Distance from treatment. 
Lentz et al. (1998) and Lentz and Sojka (1994) reported that PAM treatment reduced sediment loss rate over time with improvement of the runoff water quality parameters ortho-P, total $P$, nitrate, and biological oxygen démand. Subsequent studies have further documented the capacity of PAM treatment to reduce sediments, nutrients, and pesticides in irrigation water (Agassi et al., 1995; Singh et al., 1996; Sojka et al., 1998a,b). We hypothesized that PAM flocculates microorganisms attached to soil particles as well as microorganisms suspended in water. The PAM used in this study (Superfloc A836) is an extremely large negatively charged molecule (Lentz and Sojka, 2000; Barvenik, 1994). When PAM is combined with either $\mathrm{Al}\left(\mathrm{SO}_{4}\right)_{3}$ or $\mathrm{CaO}$ and then added to water, $\mathrm{Al}\left(\mathrm{SO}_{4}\right)_{3}$ or $\mathrm{CaO}$ should quickly disassociate, freeing $\mathrm{Al}^{+3}$ and $\mathrm{Ca}^{+2}$ to bind with anionic nutrients such as $\mathrm{H}_{2} \mathrm{PO}_{4}^{-}$and $\mathrm{NO}_{3}^{-}$. Free $\mathrm{Al}^{+3}$ and $\mathrm{Ca}^{+2}$ most likely bind with anionic sites on the PAM molecule, forming a bridge with anionic nutrients such as $\mathrm{H}_{2}$ $\mathrm{PO}_{4}^{-}$and $\mathrm{NO}_{3}^{-}$. The anionic charges on PAM would not only flocculate microorganisms, but also positively charged nutrients in wastewater.

Polyacrylamide degradation in soil is approximately $10 \% \mathrm{yr}^{-1}$ (Barvenik, 1994). Degradation of the acryamide monomer (AMD) is fairly rapid (Kay-Shoemake et al., 1998a; Shanker et al., 1990; Lande et al., 1979). Acryamide monomer was completely degraded within $5 \mathrm{~d}$ after applying $500 \mathrm{mg}$ PAM kg-1 garden soil (Shanker et al., 1990). Lande et al. (1979) applied 25 mg PAM kg-1 soil and reported that half life of an AMD in agricultural soils was 18 to $45 \mathrm{~h}$. Enrichment cultures showed that bacteria are capable of using PAM as a sole source of $\mathrm{N}$, but not $\mathrm{C}$ (Kay-Shoemake et al., $1998 \mathrm{~b}$ ). The effect of PAM application to water or soils has been shown to both increase and decrease soil microbial biomass (Nadler and Steinberger, 1993; Steinberger et al., 1993; Kay-Shoemake et al., 1998a,b).

Riparian filterstrips are currently one of the few management practices that can mitigate the input of fecal coliform bacteria from animal waste to surface and ground water (Coyne et al., 1995, 1998; Schellinger and Clausen, 1992; Walker et al., 1990; Young et al., 1980). Forest or grass filterstrips can take from months to years to establish. Therefore, the development of new technologies and management strategies to rapidly mitigate the input of nonpoint-source pollutants to surface and ground water is necessary to avoid contamination of water in many circumstances. These strategies may be especially important during filterstrip establishment phases, or when filterstrips alone cannot provide complete protection.

Sojka and Entry (2000) found reductions in active and total bacteria and fungi transferred down irrigation furrows treated with small amounts of PAM for erosion control. This initial finding prompted a closer look at improved strategies for microbial sequestration. Polyacrylamide alone significantly reduced the number of active and total bacteria in waste water. When present, PAM alone also removed active and total fungi. The efficiency of PAM to remove bacteria and fungi from water in this study is similar to values reported by Sojka and Entry (2000). Polyacrylamide reduced populations of total and fecal coliform bacteria and fecal streptococci in cattle, fish, and swine wastewater leachate and surface runoff by approximately 10 -fold ( $90 \%$ reduction) compared with no treatment. The PAM $+\mathrm{Al}\left(\mathrm{SO}_{4}\right)_{3}$ and $\mathrm{PAM}+\mathrm{CaO}$ mixtures reduced populations of total and fecal coliform bacteria and fecal streptococci in cattle, fish, and swine wastewater leachate and surface runoff by approximately 100 - to 1000 -fold compared with no treatment. Since PAM, PAM + $\mathrm{Al}\left(\mathrm{SO}_{4}\right)_{3}$, and PAM + $\mathrm{CaO}$ seem to be indiscriminate to the type and species of microorganisms removed from water, it might be expected that these mixtures could effectively remove a large range of pathogenic bacteria and fungi as well as parasitic protozoa including Cryptosporidum parvum and Giardia lamblia from flowing water. The PAM mixtures should not be expected to sterilize water, but they should be able to substantially reduced the numbers of pathogenic bacteria in wastewater prior to entering public water systems.

Polyacrylamide $+\mathrm{Al}\left(\mathrm{SO}_{4}\right)_{3}$ and $\mathrm{PAM}+\mathrm{CaO}$ compounds also significantly reduced amounts of $\mathrm{NH}_{4}^{+}$, $\mathrm{PO}_{4}^{-3}$, and total $\mathrm{P}$ in cattle and swine wastewater leachate and surface runoff. These compounds should be able to reduce these pollutants from wastewater flowing from animal confinement areas. Polyacrylamide + $\mathrm{Al}\left(\mathrm{SO}_{4}\right)_{3}$ and $\mathrm{PAM}+\mathrm{CaO}$ compounds did not remove significant amounts of $\mathrm{NH}_{4}, \mathrm{PO}_{4}$, and total $\mathrm{P}$ from fish wastewater leachate or surface runoff. However, there were substantially lower concentrations of $\mathrm{NO}_{3}^{-}, \mathrm{NH}_{4}^{+}$, $\mathrm{PO}_{4}^{-3}$, total $\mathrm{P}, \mathrm{K}, \mathrm{Ca}$, and $\mathrm{Mg}$ in fish waste than cattle or swine wastewater. If nutrient concentrations in wastewater are low there is less chance that they will contact binding sites on the PAM molecule or $\mathrm{Al}^{+3}$ and $\mathrm{Ca}^{+2}$. Therefore, $\mathrm{PAM}+\mathrm{Al}\left(\mathrm{SO}_{4}\right)_{3}$ and $\mathrm{PAM}+\mathrm{CaO}$ may be unable to remove nutrients from wastewater when nutrient concentrations are extremely low.

In general, washed sand should filter bacteria much less efficiently than most soils because water flows more freely through it than soil because there are fewer adsorptive sites and less surface area in sand compared with most soils. One might expect $\mathrm{PAM}+\mathrm{Al}\left(\mathrm{SO}_{4}\right)_{3}$ and PAM $+\mathrm{CaO}$ added to a soil surface to reduce the populations of total and fecal coliform bacteria, fecal streptococci, $\mathrm{NH}_{4}^{+}, \mathrm{PO}_{4}^{-3}$, and total $\mathrm{P}$ in leachate even more than in a washed sand column. To achieve maximum benefit, we speculate that these compounds need only be spread in a narrow strip around an animal confinement area during periods of risk prior to each rainfall. If the compounds accumulated on the soil surface, they could be removed from the soil surface and composted. Sojka (unpublished data, 1999) has incorporated up to $5600 \mathrm{~kg} \mathrm{PAM} \mathrm{ha}^{-1}$ into soil without noticeable ill effects on soil properties or plant growth.

The potential benefits of $\mathrm{PAM}+\mathrm{Al}\left(\mathrm{SO}_{4}\right)_{3}$ and $\mathrm{PAM}+\mathrm{CaO}$ compounds to animal production operations are: (i) they would be inexpensive, (ii) they could be spread on the soil surface immediately, and (iii) they could be used along with other techniques and manage- 
ment strategies such as riparian vegetation (Hubbard et al., 1998; Snyder et al., 1998; Jordan et al., 1993; Lowrance et al., 1984) and denitrification walls (Schipper and Vojvodic-Vukovic, 1998; Robertson and Cherry, 1995) to reduce the input of pollutants from animal confinement areas to water resources. Obviously, cost analysis and testing of the use of these two compounds in various animal operations is necessary, but this research demonstrates the potential of PAM + $\mathrm{Al}\left(\mathrm{SO}_{4}\right)_{3}$ and $\mathrm{PAM}+\mathrm{CaO}$ as a valuable tool to allow animal producers to control pollution from their operations. Animal production operations should not expect the development of PAM $+\mathrm{Al}\left(\mathrm{SO}_{4}\right)_{3}$ and PAM $+\mathrm{CaO}$ or any new technology to allow them to suspend best management practices or common sense. Best results of new pollution mitigation technologies will most likely be achieved by combining them with best management practices and sound animal management practices.

\section{REFERENCES}

Aase, J.K., D.L. Bjorneberg, and R.E. Sojka. 1998. Sprinkler irrigation runoff and erosion control with polyacrylamide-Laboratory tests. Soil Sci. Soc. Am. J. 62:1681-1687.

Abu-Ashour, J., D.M. Joy, H. Lee, H.R. Whiteley, and S. Zelin. 1994. Transport of microorganisms through soil. Water Air Soil Pollut. 75:141-157.

Agassi, M., J. Letey, W.J. Farmer, and P. Clark. 1995. Soil erosion contribution to pesticide transport by furrow irrigation. J. Environ. Qual. 24:892-895.

Bahr, G., and T. Steiber. 1996. Reduction of nutrient and pesticide loss through the application of polyacrylamide in surface irrigated crops. p. 41-48. In Proc. Managing Irrigation-Induced Erosion and Infiltration with Polyacrylamide, Twin Falls, ID. 6-8 May 1996. Univ. of Idaho Publ. no. 101-96. Univ. of Idaho, Moscow, ID.

Barvenik, F.W. 1994. Polyacrylamide characteristics related to soil applications. Soil Sci. 158:235-243.

Barvenik, F.W., R.E. Sojka, R.D. Lentz, F.F. Andrawes, and L.S. Messner. 1996. Fate of acrylamide monomer following application of polyacrylamide to cropland. p. 41-48. In R.E. Sojka and R.D. Lentz (ed.) Proceedings: Managing Irrigation-Induced Erosion and Infiltration with Polyacrylamide, Twin Falls, ID. 6-8 May 1996. University of Idaho, Moscow, ID.

Chen, M. 1988. Pollution of ground water by nutrients and fecal coliforms from lakeshore septic tank systems. Water Air Soil Pollut. 37:407-417.

Coyne, M.S., R.A. Gilifillen, R.W. Rhodes, and R.L. Blevins. 1995. Soil and fecal coliform trapping by grass filter strips during simulated rain. J. Soil Water Conserv. 50:405-408.

Coyne, M.S., R.A. Gilifillen, A. Villalba, Z. Zhang, R.W. Rhodes, L. Dunn, and R.L. Blevins. 1998. Fecal coliform trapping by grass filter strips during simulated rain. J. Soil Water Conserv. 52:140-145.

Deskin, R. 1996. Product stewardship considerations in the use of polyacrylamides in soil erosion. p. 31-32. In R.E. Sojka and R.D. Lentz (ed.) Proceedings: Managing Irrigation-Induced Erosion and Infiltration with Polyacrylamide, Twin Falls, ID. 6-8 May 1996. University of Idaho, Moscow, ID.

Diez-Gonzalez, F., T.R. Callaway, M.G. Kizoulis, and J.B. Russell. 1998. Grain feeding and the dissemination of acid resistant Escherichia coli from cattle. Science 281:1666-1668.

Gary, H.L., S.R. Johnson, and S.L. Ponce. 1985. Cattle grazing impact on surface water quality in a Colorado front range stream. J. Soil Water Conserv. 40:124-128.

Greenberg, A.F., L.S. Clescerl, and A.D. Eaton (ed.). 1992. Standard methods for the examination of water and wastewater. 18th ed. American Public Health Association, Washington, DC.

Hubbard, R.K., G.L. Newton, J.G. Davis, R. Lowrance, G. Vellidis, and C.R. Dove. 1998. Nitrogen assimilation by riparian buffer systems receiving swine lagoon wastewater. Trans. ASAE 41: 1295-1304.

Huysman, F., and W. Verstraete. 1993. Water facilitated transport of bacteria in unsaturated soil columns: Influence of cell surface hydrophobicity and soil properties. Soil Biol. Biochem. 25:83-90.

Ingham, E.R., and D.A. Klein. 1984. Soil fungi relationships between hyphal activity and staining with fluorescein diacetate. Soil Biol. Biochem. 16:273-278.

Jawson, M.D., L.F. Elliott, K.E. Saxton, and D.H. Fortier. 1982. The effect of cattle grazing on indicator bacteria in runoff from a Pacific Northwest watershed. J. Environ. Qual. 11:621-627.

Jenkinson, D.S., and J.M. Ladd. 1981. Microbial biomass in soil: Measurement and turnover. p. 415-471. In E.A. Paul and J.N. Ladd (ed.) Soil biochemistry. Vol 5. Marcel Dekker, New York.

Jordan, T.E., D.T. Correll, and D.E. Weller. 1993. Nutrient interception by a riparian forest receiving inputs from adjacent cropland. J. Environ. Qual. 14:467-472.

Kay-Shoemake, J.L., M.E. Watwood, R.D. Lentz, and R.E. Sojka. 1998a. Polyacrylamide as an organic nitrogen source for soil microorganisms with potential impact on inorganic soil nitrogen in agricultural soil. Soil Biol. Biochem. 30:1045-1052.

Kay-Shoemake, J.L., M.E. Watwood, R.E. Sojka, and R.D Lentz. 1998b. Polyacrylamide as a substrate for microbial amidase. Soil Biol. Biochem. 30:1647-1654.

Keeney D.R., and D.W. Nelson 1982. Nitrogen-Inorganic forms. p. 643-693. In A.L. Page et al. (ed.) Methods of soil analysis. Part 2. Chemical and microbiological properties. Agron. Monogr. 9. 2nd ed. ASA, and SSSA, Madison, WI.

Khaeel, R., K.R. Reddy, and M.R. Overcash. 1980. Transport of potential pollutants in runoff water from land areas receiving animal wastes: A review. Water Res. 14:421-436.

Kirk, R.E. 1982. Experimental design: Procedures for the behavioral sciences. 2nd ed. Brooks Cole Publ., Belmont, CA.

Lande, S.S., S.J. Bosch, and P.H. Howard. 1979. Degradation and leaching of acrylamide in soil. J. Environ. Qual. 8:133-137.

Lentz, R.D., I. Shainberg, R.E. Sojka, and D.L: Carter. 1992. Preventing irrigation furrow erosion with small applications of polymers. Soil Sci. Soc. Am. J. 56:1926-1932.

Lentz, R.D., and R.E. Sojka. 1994. Field results using polyacrylamide to manage furrow erosion and infiltration. Soil Sci. 158:274-282.

Lentz, R.D., and R.E. Sojka. 2000. Polymer charge and molecular weight effects on treated irrigation furrow processes. Int. J. Sed. Res. (in press).

Lentz, R.D., R.E. Sojka, and C.W. Robbins. 1998. Reducing phosphorus losses from surface-irrigated fields: Emerging polyacrylamide technology. J. Environ. Qual. 27:305-312.

Lodge, D.J., and E.R. Ingham. 1991. A comparison of agar film techniques for estimating fungal biovolumes in litter and soil. Agric. Ecosyst. Environ. 34:131-144.

Lowrance, R., R. Todd, J. Fail, Jr., O. Hendrickson, Jr., R. Leonard, and L. Asmussen. 1984. Riparian forests as nutrient filters in agricultural watersheds. BioScience 34:374-377.

Mallin, M.A., J.M. Burkholder, M.R. McIver, G.C. Shank, H.B. Glascow, Jr., B.W. Touchette, and J. Springer. 1997. Comparative effects of poultry and swine waste lagoon spills on the quality of receiving waters. J. Environ. Qual. 26:1622-1631.

Mawdsley, J.L., R.D. Bardgett, R.D. Merry, B.F. Pain, and M.K. Theodorou. 1995. Pathogens in livestock waste, their potential for movement through soil and environmental pollution. Appl. Soil Ecol. 2:1-15.

McMurry, S.W., M.S. Coyne, and E. Perfect. 1998. Fecal coliform transport through intact soil blocks amended with poultry manure. J. Environ. Qual. 27:86-92.

Nadler, A., and Y. Steinberger. 1993. Trends in structure, plant growth and microorganism interrelations in the soil. Soil Sci. 115:114-122.

Olsen, S.R., and L.E. Sommers. 1982. Nitrogen-Total. p. 643-710. In A.L. Page et al. (ed.) Methods of soil analysis. Part 2. Chemical and microbiological properties. Agron. Monogr. 9. 2nd ed. ASA and SSSA, Madison, WI.

Robertson, W.D., and J.A. Cherry. 1995. In situ denitrification of septic-system nitrate using reactive porus media barriers. Ground Water 33:99-111.

SAS Institute. 1996. SAS user's guide: Statistics-Version 6.03 ed. SAS Inst., Cary, NC.

Schellinger, G.R., and J.C. Clausen. 1992. Vegetative filter treatment of dairy barnyard runoff in cold regions. J. Environ. Qual. 21:40-45.

Schipper, L., and M. Vojvodic-Vukovic. 1998. Nitrate removal from groundwater using a denitrification wall amended with sawdust: Field trial. J. Environ. Qual. 27:664-668. 
Seybold, C.A. 1994. Polyacrylamide review: Soil conditioning and environmental fate. Commun. Soil Sci. Plant Anal. 25:2171-2185.

Shanker, R., C. Ramakrishna, and P.K. Seth. 1990. Microbial degradation of acrylamide monomer. Arch. Microbiol. 154:192-198.

Singh, G., J. Letey, P. Hanson, P. Osterli, and W.F. Spencer. 1996 Soil erosion and pesticide transport from an irrigated field. J. Environ. Sci. Health B31:25-41.

Smith, M.S., G.W. Thomas, R.E. White, and D. Retonga. 1985. Transport of Escherichia coli through intact and disturbed soil columns. J. Environ. Qual. 14:87-91.

Snedecor, W.G., and W.G. Cochran. 1980. Statistical methods. 7th ed. Iowa State Univ. Press, Ames.

Snyder, N.J., S. Mostaghimi, D.F. Berry, R.B. Reneau, S. Hong, P.W McClellan, and E.P. Smith. 1998. Impact of riparian buffers on agricultural nonpoint source pollution. J. Am. Water Resour. Assoc. 34:385-395.

Sojka, R.E., and J.A. Entry. 2000. Influence of polyacrylamide application to soil on movement of microorganisms in runoff water. Environ. Pollut. 108:405-412.

Sojka, R.E., R.D. Lentz, C.W. Ross, T.J. Trout, D.L. Bjorneberg, and J.K. Aase. 1998a. Polyacrylamide effects on infiltration in irrigated agriculture. J. Soil. Water. Conserv. 54:325-331.

Sojka, R.E., R.D. Lentz, and D.T. Westermann. 1998b. Water and erosion management with multiple applications of polyacrylamide in furrow irrigation. Soil Sci. Soc. Am. J. 62:1672-1680.
Stamatiadis, S., J.W. Doran, and E.R. Ingham. 1990. Use of staining inhibitors to separate fungal and bacterial activity in soil. Soil Biol. Biochem. 22:81-88.

Steinberger, Y., S. Sarig, A. Nadler, and G. Barnes. 1993. The effect of synthetic soil conditioners on microbial biomass. Arid Soil Res. Rehabil. 7:303-306.

USEPA. 1998. Environmental impacts of animal feeding operations. Preliminary data summary. Feedlots Point Source Category Study. USEPA Office of Water, Standards and Applied Sciences Division, Washington, DC.

Van Elsas, J.D., J.T. Trevors, and L.S. Overbeek. 1991. Influence of soil properties on the vertical movement of genetically marked Pseudomonas fluorescens through large soil columns. Biol. Fertil. Soils 10:249-255.

Walker, S.E., S. Mostaghimi, T.A. Dillaha, and F.E. Woest. 1990. Modeling animal waste management practices: Impacts on bacteria levels in runoff from agricultural land. Trans. ASAE 33:807-817.

West, A.W., D.J. Ross, and J.C. Cowling. 1986. Changes in microbial $C, N, P$, and ATP contents, numbers and respiration on storage of soil. Soil Biol. Biochem. 18:141-148.

Young, R.A., T. Hundtrods, and W. Anderson. 1980. Effectiveness of vegetated buffer strips in controlling pollution from feedlot runoff. J. Environ. Qual. 9:483-487. 